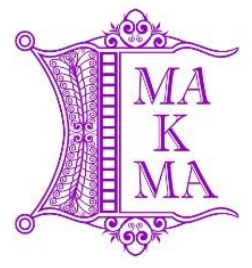

Majalah Kesehatan Masyarakat Aceh (MaKMA) http://ojs.serambimekkah.ac.id/index.php/makma

\title{
PERBEDAAN NILAI SEBELUM DAN SETELAH PROGRAM WEEKLY SAFETY TALK PADA PEKERJA DI PT. BUMI SUKSESINDO BANYUWANGI
}

\section{Meidyas Dwi Anggraeni, Septa Indra Puspikawati}

Fakultas Kesehatan Masyarakat PSDKU Universitas Airlangga di Banyuwangi

Alamat Korespondensi: Lingkungan Krajan Giri Banyuwangi. Email: meidyas.dwi.anggraeni2015@fkm.unair.ac.id. No H: 081233590950

\begin{abstract}
ABSTRAK
Komunikasi Keselamatan kerja merupakan bagian dari kegiatan pendukung untuk pencegahan kecelakaan kerja. Salah satu upaya pencegahan yang ada dalam K3 adalah melaksanakan program safety talk di tempat kerja guna mencegah adanya kecelakaan kerja dengan tetap menjaga komunikasi antar pekerja dengan baik. Tujuan penelitian ini adalah untuk menganalisis perbedaan nilai sebelum dan sesudah pemberian program weekly safety talk pada pekerja di PT. Bumi Suksesindo. Jenis penelitian ini adalah observasional dengan desain penelitian cross sectional. Penelitian ini dilakukan pada pekerja PT. Bumi Suksesindo, Pesanggaran Banyuwangi tahun 2019. Sampel dari penelitian ini berjumlah 99 pekerja dari departemen di PT. Bumi Suksesindo yang dipilih melalui random sampling. Variabel penelitian ini adalah program weekly safety talk dan juga pengetahuan pekerja. Hasil penelitian menunjukkan bhawa sebagaian besar responden memiliki usia 26 - 35 tahun dan berpendidikan SMA. Hasil analisis menunjukkan bahwa rata rata nilai pekerja sebelum dilakukan weekly safety talk adalah 66,92, sedangkan setelah diberikan weekly safety talk adalah 79,42, maka terjadi peningkatan rata - rata nilai sebelum dan sesudah dilakukan weekly safety talk. Diketahui juga nilai $\mathrm{p}$ value $=0,000$ yang artinya nilai sesudah dilakukan weeklysafety talk signifikan lebih besar dibandingkan dengan sebelum dilalukan weekly safety talk. Kesimpulan dari penelitian ini adalah terdapat perbedaan nilai sebelum dan sesudah diberikan weekly safety talk pada pekerja PT. Bumi Suksesindo, maka dapat dikatakan bahwa pelaksanaan weekly safety talk berjalan dengan baik. PT. Bumi Suksesindo diharapkan dapat berinovasi untuk program safety talk yang lebih baik lagi sebagai langkah peningkatan pemahaman pekerja tentang K3 seperti dengan menggunakan media visual atau audio visual dalam beberapa waktu.
\end{abstract}

Kata Kunci : Weekly Safety Talk, Uji T, Rata - rata 


\title{
The Differences Value Before and After Weekly Safety Talk Program to Workers at PT. Bumi Suksesindo Banyuwangi
}

\begin{abstract}
Communication Work safety is part of supporting activities for the prevention of workplace accidents. One of the prevention efforts in $\mathrm{K} 3$ is to carry out a talk safety program in the workplace to prevent work accidents while maintaining good communication between workers. The purpose of this study was to analyze differences in values before and after the weekly safety talk program for workers at PT. Bumi Suksesindo. The type of this research is observational with cross sectional research design. This research was conducted at PT. Bumi Suksesindo, Pesanggaran Banyuwangi in 2019. Samples from this study amounted to 99 workers from the department at PT. Bumi Suksesindo selected through random sampling. The variable of this research is the weekly safety talk program and also knowledge of workers. The results of the study showed that most of the respondents had ages 26-35 years and had high school education. The results of the analysis show that the average value of workers before the weekly safety talk is 66.92 , whereas after being given the weekly safety talk is 79.42 , there is an increase in the average value before and after the weekly safety talk. It is also known that the $\mathrm{p}$ value $=0,000$ which means that the value after weekly weekly socialization is significantly greater than before the weekly safety talk. The conclusion of this study is that there are differences in values before and after the weekly safety talk given to workers at PT. Bumi Suksesindo, it can be said that the implementation of the weekly safety talk is going well. PT. Bumi Suksesindo is expected to be able to innovate for a better safety talk program as a step to increase workers' understanding of K3 such as by using visual or audio-visual media for some time.
\end{abstract}

Keywords: Weekly safety talk, T-Test, Means 


\section{PENDAHULUAN}

Kecelakaan kerja mempunyai tingkat kategori keparahan yang berbedabeda yaitu "ringan", "sedang" dan "parah". Namun kecelakaan dari kategori apapun harus dianggap penting oleh manajemen termasuk dalam kategori ringan atau minor injury. Berdasarkan penelitian di Malaysia, terlihat rasio terjadinya kecelakaan dengan perbandingan 1:12:60, dimana setiap 60 near miss dapat berakibat 12 kecelakaan ringan (minor injury) atau 1 cidera serius (major injury) ${ }^{[1]}$.

International Labour Organization (ILO) menyatakan, setiap harinya terjadi sekitar 6.000 kecelakaan kerja fatal didunia, 1 pekerja di dunia meninggal setiap 15 detik karena kecelakaan kerja ${ }^{[2]}$. Indonesia tingkat kecelakaan kerja merupakan salah satu yang tertinggi di dunia, pada tahun 2011- 2014 terjadi 92.444 kasus kecelakaan kerja. Kecelakaan kerja paling tinggi terjadi pada tahun 2013 yaitu terdapat 35.917 kasus kecelakaan kerja. Hal tersebut didukung dengan jumlah kecelakaan kerja pertambangan di Indonesia, terdapat 91 total kecelakaan kerja di pertambangan Indonesia yang terdiri dari 29 cidera ringan, 54 cidera berat, dan meninggal 8 dari bulan Januari Oktober $2017^{[3]}$.

Pemenuhan terhadap tercapainya tujuan penerapan $\mathrm{K} 3$ di tempat kerja, berpedoman pada dasar undang-undang penerapan Keselamatan Kerja di tempat kerja yaitu UU No. 1 Tahun 1970 dan juga Kepmen ESDM Nomor 1827.K/30/MEM/2018 tentang Pedoman Pelaksanaan Kaidah Teknik Pertambangan Yang Baik. Peraturan tersebut mengatur tentang pengelolaan keselamatan pertambangan, dengan ruang lingkup Keselamatan dan Kesehatan Kerja (K3), Kesekanatab Operasi (KO), dan Sistem Manajemen Keselamatan Pertambangan Mineral dan Batu Bara (SMKP Minerba). Dalam menjamin perlindungan pekerja terhadap keselamatan dan kesehatan kerja perusahaan berpedoman pada UU No. 13 Tahun 2003 tentang ketenagakerjaan yang memberikan perhatian khusus pada pasal 35 ayat 3 , pasal 86 ayat 2 dan pasal 87 ayat 1 serta melakukan sertifikasi OHSAS 18001 serta ISO 14001.

Penerapan SMK3 dalam PP 50 tahun 2012, menyebutkan bahwa komunikasi K3 merupakan bagian dari kegiatan pendukung untuk pencegahan kecelakaan kerja. Salah satu upaya pencegahan yang ada dalam K3 adalah melaksanakan program Safety talk di tempat kerja. Safety talk merupakan salah satu sarana penunjang dalam upaya mencegah terjadinya bahaya di tempat kerja [1].

PT. Bumi Suksesindo merupakan perusahaan tambang yang juga menerapkan program safety talk yang dinamakan weekly safety talk sebagai bentuk komunikasi K3. Program Weekly Safety Talk dilakukan untuk mencegah atau meminimallkan resiko pada pekerjaan yang akan dilakukannya. Kegiatan ini merupakan salah satu sarana penunjang dari sekian banyak metode yang ada dalam upaya pencegahan kecelakaan dan mengingatkan karyawan atau pekerja akan potensi bahaya di tempat kerja dan membantu karyawan/pekerja untuk mengenali bahaya tersebut. Weekly safety talk dilakukan dalam 1 minggu sekali dengan mengangkat tema - tema keselamatan yang baru atau mengangkat tentang kecelakaan kerja serta kesehatan kerja yang ada di PT. Bumi Sukesindo yang dilakukan oleh Departemen OHS (Occupational Health and Safety). Selama adanya program tersebut belum adanya penilaian tentang peningkatan pengetahuan karyawan setelah diberikan weekly safety talk, dengan begitu perlu dilakukan penelitian tentang adanya hubungan antara weekly safety talk dengan peningkatan pengetahuan pekerja PT. Bumi Suksesindo. 


\section{METODE}

Jenis penelitian ini adalah observasional dengan desain penelitian cross sectional yang bertujuan untuk mengetahui perbedaan nilai rata - rata sebelum dan sesudah diberikan weekly safety talk pada pekerja PT. Bumi Suksesindo. Lokasi penelitian adalah di PT. Suksesindo Pesanggaran, Kabupaten Banyuwangi. Penelitian dilakukan pada bulan Maret 2019.

Populasi penelitian ini adalah pekerja di PT. Bumi Suksesindo. Sampel yang digunakan sebanyak 99 pekerja dari seluruh departemen yang ada di PT dengan jumlah pekerja 2200 pekerja. Bumi Suksesidno yang diambil menggunakan perhitungan dengan rumus slovin dan diambil pada menggunakan teknik random sampling. Variabel penelitian ini adalah program

\section{HASIL}

Berdasarkan [Tabel. 1] diketahui bahwa responden didominasi oleh pekerja yang berusia antara 26 - 35 tahun sebanyak 32 pekerja (32,3\%), sedangkan untuk karakteristik pekerja berdasarkan pendidikan didominasi oleh pekerja dengan tingkat pendidikan SMA sebanyak 58 pekerja $(58,16 \%)$.

Pada [Tabel. 2] diperoleh rata - rata nilai pretest adalah sebebsar 66,92, sedangkan nilai posttest setelah diberikan weekly safety talk rata ratanya adalah 79,42 yang artinya terdapat peningkatan pengetahuan setelah dilakukannya program weekly safety talk. weekly safety talk dan peningkatan pengetahuan pekerja. Penelitian ini menggunakan instrumen berupa kuesioner berdasarkan materi yang diberikan yakni topik titik jepit yang terdiri dari 10 pertanyaan dengan pertanyaan multiple choice dengan masing - masing jawaban benar mendapatkan nilai 10 dan salah mendapatkan nilai 0 . Teknik analisis data menggunakan uji $\mathrm{T}$ berpasangan dengan mengukur hubungan weekly safety talk yang dilakukan setiap minggu dengan adanya peningkatan pengetahuan pekerja dengan kuesioner pre dan post test, pre test diberikan sebelum pekerja mendapatkan materi tentang titik jepit dan post test diberikan setelah pekerja mendapatkan materi tentang titik jepit oleh Departemen OHS.

Hasil analisis SPSS uji $t$ berpasangan diperoleh thitung sebesar 6,611, dalam uji t tanda plus maupun minus tidak diperhatikan sehingga $t_{\text {hitung }}$ $>t_{\text {tabel }}(-6,611>1,98447)$, dari hasil tersebut disimpulkan bahwa $\mathrm{H}_{0}$ ditolak dan $\mathrm{H}_{1}$ diterima, maka dapat disimpulkan bahwa teradapat perbedaan rata - rata nilai sebelum dan sesudah diberikan weekly safety talk pada pekerja PT. Bumi Suksesindo.

Berdasarkan hasil analisis, diperoleh nilai signifikasi sebesar 0,000 dengan begitu artinya nilai sig $0,000<0,05$, maka nilai rata - rata sesudah diberikan program weekly safety talk signifikan lebih besar dibandingkan dengan sebelum diberikan weekly safety talk pada pekerja di PT. Bumi Suksesindo. 


\section{PEMBAHASAN}

Kecelakaan merupakan hal yang tidak diinginkan oleh perusahaan bahkan hal ini harus dihindari, terutama ketika kecelakaan itu terjadi pada karyawan perusahaan yang dapat membahayakan jiwa. Terdapat dua faktor yang menyebabkan kecelakaan terjadi, yang pertama adalah faktor individu, dan yang kedua adalah faktor lingkungan. Faktor individu yang dapat menyebabkan kecelakaan kerja salah satunya adalah kurangnya komunikasi atau kegagalan dalam berkomunikasi ${ }^{[4]}$.

Salah satu program komunikasi kesehatan dalam lingkungan kerja adalah safety talk. Safety talk merupakan salah satu program pengendalian kecelakaan yang dilakukan dengan pendekatan personal dimana $85 \%$ kecelakaan disebabkan oleh faktor individu atau faktor manusia. Safety talk dilakukan secara rutin antara karyawan dengan Supervisor HSE untuk membicarakan hal - hal mengenai keselamatan dan kesehatan kerja.

Penelitian ini didominasi oleh pekerja dengan usia 26 - 35 tahun dimana menurut Departemen Kesehatan tahun 2009 tergolong dalam kategori dewasa awal. Sedangkan untuk karakteristik pendidikan responden didominasi oleh pekerja dengan tamat SMA. Perbedaan nilai rata - rata sebelum dan sesudah diberikan weekly safety talk manunjukkan bahwa program weekly safety talk dapat meningkatkan pengetahuan pekerja sehingga setelah dilakukan program tersebut, nilai rata - rata dari para pekerja meningkat secara signifikan. Penelitian ini sejalan dengan penelitian lain pada tahun 2017 pada PT. Kusumahadi Santosa Karanganyar yang menyatakan bahwa terdapat pengaruh yang signifikan dari pemberian safety talk dalam meningkatkan pengetahuan dan kepatuhan penggunaan alat pelindung diri pada pekerja ${ }^{[5]}$.
Hal ini juga di perkuat dari hasil penelitian mengenai safety talk pada tahun 2011, yang menunjukkan program safety talk yang dilakukan sebelum bekerja sangat efektif dalam memenuhi kebutuhan karyawan dalam informasi mengenai K3 dan membangun kesadaran para karyawan untuk mengutamakan safety untuk mencegah terjadinya kecelakaan kerja ${ }^{[6]}$.

Weekly safety talk berhubungan dengan peningkatan pengetahuan pekerja karena pemberian materi dilakukan pada pagi hari selama 30 menit sebelum pekerja melakukan pekerjaannya. Belajar di pagi hari lebih efektif dilakukan dibandingkan dengan waktu lainnya karena kondisi jasmani dan rohani masih segar (fresh) dan memori otak masih kosong, sehingga bisa dengan mudah menerima atau menyerap materi yang diberikan. Pada saat pelaksanaan weekly Safety talk juga dilakukan dengan sistem diskusi yang mana terdapat sesi tanya jawab, bukan hanya pekerja kepada pemateri tetapi pemateri juga akan memberikan pertanyaan kepada pekerja tentang apa yang dijelaskan. Materi juga disajikan dengan bahasa - bahasa yang mudah dimengerti oleh pekerja dan mengambil contoh materi dari apa yang pekerja kerjakan di PT. Bumi Suksesindo.

Menurut penelitian terdahulu tentang Impact of Safety Communication on Safety Commtiment with Leader-Member Exchange Quality as A Moderating Factor: A Conceptual Frame Work yang menyimpulkan bahwa variabel komunikasi keselamatan memiliki pengaruh yang signifikan terhadap keselamatan kerja [7]. Komunikasi keselamatan berpengaruh terhadap berpengaruh signifikan terhadap keselamatan kerja di PT. Bumi Sukesindo, karena pada umumnya dalam melakukan berbagai kegiatan yang bersangkutan dengan keselamatan kerja perlu adanya komunikasi yang yang 
dilakukan oleh seluruh jajaran managemen dari atasan kebawahan ,karyawan ke karyawan sehingga komunikasi dalam keselamatan kerja merupakan hal yang sangat penting dan berpengauh. Oleh karena itu, perusahann harus lebih memperhatikan komunikasi sebagai salah satu faktor penunjang keselamatan kerja.

Berbeda dengan penelitian yang pernah dilakukan pada tahun 2017 yang menjelaskan bahwa safety morning talk tidak menunjukkan hubungan yang berarti dengan kepatuhan pekerja ${ }^{[1]}$. Hal tersebut dikarenakan pemahaman dari pekerja yang berbeda - beda, tergantung dari latar belakang pendidikan masing -

\section{KESIMPULAN DAN SARAN}

Berdasarkan hasil penelitian yang dilakukan, maka disimpulkan bahwa terdapat perbedaan rata - rata antara sebelum dan sesudah diberikan weekly safety talk dan nilai rata - rata setelah dilakukan safety talk signifikan lebih besar dibandingkan sebelum dilakukan safety talk pada pekerja PT. Bumi Sukseindo, Pesanggaran, Kabupaten Banyuwangi, maka dapat dinyatakan

\section{DAFTAR PUSTAKA}

1. Kurniawan W, dkk. 2017. Hubungan Faktor Karakteristik Pekerja, Safety Morning Talk (SMT) dan Housekeeping Dengan Kejadian Minor Injury pada Pekerja di Proyek Pembangunan Gedung Kantor PT. X Jakarta.

2. International Labour Organization. 2013 . Keselamatan dan Kesehatan Kerja di Tempat Kerja (Sarana untuk Produktivitas). Modul 5. Edisi Bahasa Indonesia. Jakarta : ILO

3. Direkotrat Jenderal Mineral dan Batubara Kementrian Energi dan masing pekerja dan mayoritas pekerja hanya tamat SD, SMP dan SMA.

Keterbatasan pada penelitian ini adalah kegiatan pre-test dan post-test, dilakukan dalam waktu yang singkat, sehingga memungkinkan pekerja menjawab pertanyaan pada kuesioner dengan jawaban yang sama antara pretest dan post-test, sedangkan kelebihan pada penelitian ini adalah dapat menilai pemahaman tentang materi yang diberikan kepada pekerja.

Penelitian ini diharapkan dapat menjadi kajian untuk penelitian lain yang serupa khususnya tentang hubungan program safety talk terhadap tingkat pengetahuan pada pekerja.

bahwa program weekly safety talk dapat berjalan dengan baik di PT. Bumi Suksesindo. Safety talk yang sudah dilakukan dengan baik diharapkan dapat ditingkatkan dan dapat dikembangkan dengan inovasi - inovasi menggunakan media visual atau audio visual sehingga membuat pekerja lebih tertarik dengan materi yang diberikan dan membuat materi yang diberikan dapat diterima dengan baik oleh para pekerja.

Sumber Daya Mineral, 2017. Tingkat Kekerapan dan Keparahan Kecelakaan Tambang Tahun 2017.

4. Suma'mur. 2014. Hygiene Perusahaan dan Kesehatan Kerja (HIPERKES). Jakarta: CV. Sagung Seto.

5. Candra SA. 2017. Pengaruh Pemberian Safety Talk Terhadap Peningkatan Pengetahuan dan Kepatuhan Penggunaan Alat Pelindung Diri pada Pekerja Bagian Weaving 2 PT. Kusumahadi Santosa Karanganyar. 
6. Anggia, Nur. 2011. Efektivitas Komunikasi Safety Talk Sebagai Pemenuhan Informasi K3 Bagi Karyawan PT.Multikon. Rashid RA, dkk. 2014. Impact of Safety
Communication on Safety Commtiment with Leader-Member Exchange Quality as A Moderating Factor: A Conceptual Frame Work. 


\section{LAMPIRAN}

Tabel [1]. Karakteristik Responden PT. Bumi Sukesindo Banyuwangi pada Tahun 2019

\begin{tabular}{lcc}
\hline Variabel & Frekuensi & Persentase (\%) \\
\hline Usia (Tahun) & & \\
$17-25$ & 24 & 24,3 \\
$26-35$ & 32 & 32,2 \\
$36-45$ & 27 & 27,3 \\
$46-55$ & 15 & 15,2 \\
$56-65$ & 1 & 1 \\
Total & 99 & 100 \\
\hline Pendidikan & & \\
\hline SD & 4 & 4 \\
SMP & 30 & 30,3 \\
SMA & 58 & 58,6 \\
Sarjana & 7 & 7,1 \\
Total & 99 & 100 \\
\hline Sumber : Dat Primer 2019 & &
\end{tabular}

Tabel [2]. Hasil Uji T Nilai Pre test dan Post test Pekerja di PT. Bumi Suksesindo pada Tahun 2019

\begin{tabular}{cccccc}
\hline Nilai & Mean & t hitung & t tabel & Signifikansi & p-value \\
\hline Sebelum & 66,92 & $-6,611$ & 1,98447 & 0,05 & 0,000 \\
Sesudah & 79,42 & & & & \\
\hline
\end{tabular}

